\title{
Effect of phenophase based irrigation schedules on growth, yield and quality of baby corn (Zea mays L.)
}

\author{
H. K. Shivakumar, B. K. Ramachandrappa, H. V. Nanjappa, Mudalagiriyappa
}

Department of Agronomy, University of Agricultural Sciences, Bangalore, India.

Received 3 May 2011; revised 23 Jnue 2011; accepted 29 July 2011.

\begin{abstract}
The field experiment was conduced at the Agronomy Field Unit, Main Research Station, University of Agricultural Sciences, Hebbal, Bangalore, India during 2002 and 2003 to study the effect of irrigation schedules on growth, yield and quality of baby corn. The soil of the experimental site was red sandy loam in texture with neutral reaction. The experiment was laid out in a randomized complete block design with three replications. There were seven treatments of irrigation schedules based on IWICPE ratio of 0.6 and 1.0 during different phenophases of baby corn. The results of the experiment revealed that the baby corn dry matter was significantly higher $\left(75.57 \mathrm{~g} \cdot\right.$ plant $^{-1}$ ) with higher green fodder yield of $43.47 \mathrm{t}^{-h^{-1}}$ due to irrigation scheduled at IWICPE ratio of 1.0 followed by moisture stress at early stage $\left(I_{3}\right)$. Irrigations scheduled at IWI CPE ratio of 1.0 registered significantly higher baby corn yield of $6.60 \mathrm{t} \cdot \mathrm{ha}^{-1}$ followed by the delayed irrigation at early stage of $10-25$ DAS. Significantly higher crude protein, phosphorus, potassium and lower reducing sugars and ascorbic acid content of baby corn was recorded under IWICPE ratio of 1.0. Delayed irrigation at 0.6 IWICPE ratio throughout produced baby corn with higher taste and juiciness. The total crop water use ranged from 294.10 to 469.10 $\mathrm{mm}$, respectively under continuously delayed irrigation at 0.6 IW/CPE ratio and frequent irrigation at IWICPE ratio of 1.0 which also recorded higher water use efficiency.
\end{abstract}

Keywords: Baby Corn; Irrigation Schedule; IW/CPE Ratio; Yield; Soil Moisture; Stress Day Index

\section{INTRODUCTION}

Baby corn is the unpollinated, immature ear of any corn genotype (Zea mays L.) harvested 2 or 3 days after silk emergence, depending upon developmental conditions of the plant and the size of the shoot. The young ear, an offshoot of grain maize, dehusked and desilked is served as a raw vegetable. Its delicate, sweet flavor and crisp nature contributes to its increasing popularity making an indispensable ingredient in many fancy dishes of city elite and middle class people. The wonder vegetable with low calories, high in fiber and low in cholesterol provides tremendous avenues for crop diversification, crop intensification, value addition and revenue generation. Since it is a short duration crop unlike the other versions of maize, agro-techniques like hydro-nutritional requirements have to be standardized for the highest yield with best quality to realize higher economic returns.

Scientific irrigation scheduling should go with an understanding of soil-water-atmospheric relationship. The ratio between a fixed amount of irrigation water (IW) and cumulative pan evaporation (CPE) from an USWB open pan evaporimeter minus effective rainfall since previous irrigation is used as a basis for scheduling irrigation to crops. Prihar et al. [1] suggested a meteorological approach based on the ratio between IW and CPE for scheduling irrigation. In this particular study the concept of IW/CPE ratio which is a reliable, economical and practical method for scheduling of irrigation as suggested by Prihar et al. [2] has been adopted. Not much information is available on the phenophased irrigation schedule of short duration crops like baby corn under semiarid tropics. Hence, the present investigation was carried out to study the effect of irrigation schedules on growth, yield and quality of baby corn.

\section{MATERIALS AND METHODS}

\subsection{Study Site}

The experiment was conduced at the Agronomy field unit, Main Research Station, University of Agricultural Sciences, Hebbal, Bangalore, India during January- 
March season (summer) of 2002 and 2003. The soil of the experimental site was red sandy loam in texture with neutral soil reaction (7.58) and electrical conductivity of $0.20 \mathrm{~d} \cdot \mathrm{Sm}^{-1}$. The available $\mathrm{N}, \mathrm{P}_{2} \mathrm{O}_{5}$ and $\mathrm{K}_{2} \mathrm{O}$ were 225.9, 33.66 and $221.5 \mathrm{~kg} \cdot \mathrm{ha}^{-1}$ respectively before the initiation of the first year experiment. The hydrological properties revealed that $13.54 \%, 18.83 \%, 19.50 \%$ and $17.97 \%$ moisture held at field capacity (0.03 M Pa) for 0 - 15, 15 - 30, 30 - 60 and 60 - $90 \mathrm{~cm}$ depths and permanent wilting point values $(-1.5 \mathrm{M} \mathrm{Pa})$ for the corresponding depths were $7.83 \%, 12.00 \%, 12.12 \%$ and $11.91 \%$, respectively. The bulk density of the soil in the upper 90 $\mathrm{cm}$ was $1.61 \mathrm{~g} / \mathrm{cc}$. The weather was warm and effective rainfall of $8.2 \mathrm{~mm}$ was received during the actual crop growth period in 2002. The actual maximum and minimum temperature and $\mathrm{RH}$ was higher than the normal during the crop growth period. However, actual open pan evaporation, wind velocity and bright sunshine hours were lower than the normal during the crop growth period 2002 and 2003 creating favourable weather conditions for the crop growth. Baby corn hybrid PAC 792 was sown on $1^{\text {st }}$ January, 2002 and $14^{\text {th }}$ January, 2003, at the spacing of $45 \mathrm{~cm}$ between the rows and $30 \mathrm{~cm}$ within the row. Two healthy plants were retained per hill.

\subsection{Experimental Set up}

The experiment was laid out in a randomized complete block design with three replications in $4.5 \mathrm{~m} \times 3 \mathrm{~m}$ plots. After the plots were prepared to the requirement, 10 tones of farm yard manure were incorporated into soil, fifteen days before sowing. The nutrients were applied at 150:75:40 $\mathrm{kg} \mathrm{NPK} \cdot \mathrm{ha}^{-1}$ in the form of urea, single super phosphate and muriate of potash. Fifty per cent of $\mathrm{N}$ and full dose of $\mathrm{P}$ and $\mathrm{K}$ were applied at the time of sowing, while the remaining fifty per cent of $\mathrm{N}$ was top dressed during earthing up to a 30 days old crop. Weeds were controlled with pre-emergent application of atrazine herbicide at $12.5 \mathrm{~kg} \cdot \mathrm{ha}^{-1}$ coupled with a hand weeding at 30 days of crop growth. Two common surface irrigations amounting to $70(40+30)$ and $60(30+30) \mathrm{mm}$ were given for better crop establishment during 2002 and 2003, respectively. The crop growth period was divided into three stages viz., vegetative (10 - 25 DAS), grand growth (26 - 40 DAS) and baby corn development stages (41 DAS to harvest). Later, seven irrigation schedules (Table 1) were imposed based on IW/CPE ratios of 0.6 and 1.0 during different phenophases of baby corn crop growth from $10^{\text {th }}$ day of sowing measured using Parshall flume. At each irrigation, $50 \mathrm{~mm}$ depth of water was applied. There were 4 - 7 and 5 - 9 numbers of irrigations depending on the irrigation schedule in two years of experimentation respectively. Irrigation canals were lined with black polythene sheet to avoid lateral move-
Table 1. Treatment details.

\begin{tabular}{cccc}
\hline \multicolumn{4}{c}{ Irrigation schedules (IW/CPE) } \\
\hline Treatment & 10 - 25 DAS & 26 - 40 DAS & 41 DAS-Harvest \\
$\mathrm{I}_{1}$ & 1.0 & 1.0 & 1.0 \\
$\mathrm{I}_{2}$ & 0.6 & 0.6 & 0.6 \\
$\mathrm{I}_{3}$ & 0.6 & 1.0 & 1.0 \\
$\mathrm{I}_{4}$ & 1.0 & 0.6 & 1.0 \\
$\mathrm{I}_{5}$ & 1.0 & 1.0 & 0.6 \\
$\mathrm{I}_{6}$ & 0.6 & 0.6 & 1.0 \\
$\mathrm{I}_{7}$ & 1.0 & 0.6 & 0.6 \\
\hline
\end{tabular}

ment of water. Detasseling was done as and when the tassel emerged to avoid pollination and fertilization.

\subsection{Data Collection and Analysis}

The data on growth yield and quality of baby corn has been documented focusing the objectives of study. The nitrogen (modified Kjeldhal's), phosphorus (molybdophosphoric acid yellow colour in $\mathrm{HNO}_{3}$ system) and potassium concentration (Diacid digested samples in flame photometer) in oven dried baby corn samples was estimated. From the concentration of $\mathrm{N}$ in baby corn, crude protein content was calculated by multiplying with the factor 6.25. Ascorbic acid [3], reducing sugars [4] and crude fiber content of baby corn [5] were determined using standard procedure. Sensory evaluation of baby corn was judged by a jury of $10-15$ members (food and nutrition specialists) for its appearance, colour, texture, taste and juiciness on a five point scale as given in Table 4. The pooled results of 2002 and 2003 years are presented and discussed with respect to irrigation schedules.

The total water requirement was determined by adding the water applied at all the irrigations and effective rainfall received during the crop growth period. The water use efficiency was worked out as the ratio of the yield of baby corn or the yield of green fodder to the amount of water used and expressed as $\mathrm{kg} \cdot \mathrm{ha} \cdot \mathrm{mm}^{-1}$.

\section{RESULTS AND DISCUSSION}

\subsection{Growth}

Economic yield is a part of the total biological yield of the crop and hence the dry matter production is an important pre-requisite for higher yields as it signifies photosynthetic ability of the crop and also indicates other synthetic processes during developmental sequences. Maintenance of adequate moisture by irrigation at IW/CPE ratio of $1.0\left(\mathrm{I}_{1}\right)$ established significantly higher total dry matter (75.57 g.plant ${ }^{-1}$ ) and green fodder yield $\left(43.47 \mathrm{t}^{\mathrm{h}} \mathrm{ha}^{-1}\right)$ over rest of the treatments and was followed by moisture stress at early stage $\left(\mathrm{I}_{3}\right)$. Delayed irrigations successively up to harvest $\left(\mathrm{I}_{2}\right)$ recorded sig- 
nificantly lower total dry matter production apart from the green fodder yield (Table 2). The higher total dry matter and green fodder yield at 1.0 IW/CPE ratio are favorably influenced by higher plant height at harvest $(155.5 \mathrm{~cm})$ and leaf area index (4.43). Higher leaf number, expansion and duration of leaf area coupled with higher light interception (69.85\%) under adequate moisture condition have contributed for more dry matter accumulation and translocation of photosynthates from source to sink, eventually resulting in higher yield attributes. The importance of canopy structure in light interception, crop growth and yield has been pointed out by Duncan [6]. In baby corn, Sundarsingh [7] reported higher plant height $(231.00 \mathrm{~cm})$ and dry matter production (13.50 tha $\left.\mathrm{th}^{-1}\right)$ due to irrigation at IW/CPE ratio of 1.0 over 0.5 and 0.75 ratios. Similar results were also registered by Hussain et al. [8].

\subsection{Yield and Quality}

Irrigations scheduled at IW/CPE ratio of 1.0 registered significantly higher baby corn yield of $6.60 \mathrm{t}^{\mathrm{h}} \mathrm{ha}^{-1}$ followed by the delayed irrigations at early stage of $10-25$ DAS. On the other hand, continuously delayed irrigation at IW/CPE ratio of 0.6 registered significantly lower baby corn yield of $3.82 \mathrm{t} \cdot \mathrm{ha}^{-1}$ over all other treatments but was on par with stress induced after 26 DAS till harvest (4.34 $\left.\mathrm{t}^{\mathrm{h}} \mathrm{ha}^{-1}\right)$ (Table 3). The increased baby corn yield was mainly due to adequate moisture availability and increased nutrients uptake throughout the crop growth stages, having beneficial effect on yield contributing factors. This clearly indicates the need for optimum moisture level in soil which results in negative effect on yield at both the extremes of moisture level, during different phases of crop growth. Kaliappa et al. [9] observed significantly higher grain yield of maize at $75 \%$ and $50 \%$ available soil moisture deficit (ASMD) during vegetative and reproductive growth stages respectively. With respect to quality parameters, significantly higher crude protein, phosphorus and potassium content $(18.90 \%, 0.44 \%$ and $2.82 \%$, respectively) of baby corn under regular irrigations of $1.0 \mathrm{IW} / \mathrm{CPE}$ ratio was mainly due to adequate uptake of nutrients by the crop during its entire crop growth stage due to favourable soil moisture regime and nutrient supply (Table 3 ). Singh et al. [10] reported significantly increased crude protein and carbohydrates content due to irrigation scheduled at 1.2 IW/CPE ratio as compared to 0.6 ratio. On the contrary, delayed irrigations at 0.6 IW/CPE ratio throughout caused for significantly higher reducing sugars and ascorbic acid content while the crude fiber content was lower followed by successive stress treatments from 26 DAS to harvest. Increased sugars and ascorbic acid content under moisture stress is an established phenomenon of stressed plants to accumulate these osmolytes to combat drought stress. Bharathi et al. [11] recorded higher sugar and amino acid and lower protein content and dehydrogenase activity with 0.5 IW/CPE ratio as against IW/CPE ratio of 0.75 in maize. Sundarsingh [7] also revealed higher crude protein and ascorbic acid content of baby corn due to irrigation at $1.0 \mathrm{IW} / \mathrm{CPE}$ ratio over 0.5 and 0.75 ratios.

\subsection{Sensory Parameters}

When the organoleptic tests were carried out to know

Table 2. Growth parameters of baby corn as influenced by irrigation schedules (Pooled data of 2002 and 2003).

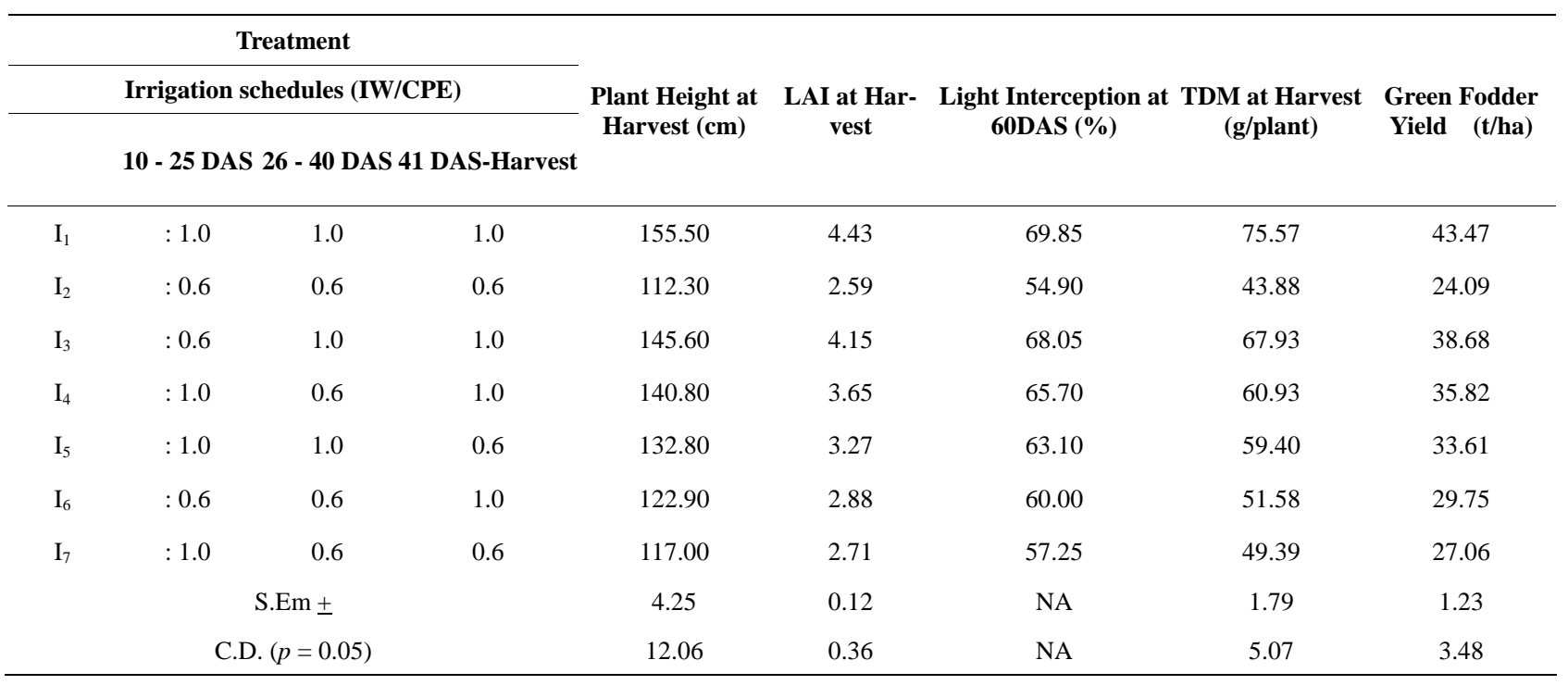

NA - Not Analysed 
Table 3. Yield and quality of baby corn as influenced by irrigation schedules (Pooled data of 2002 and 2003).

\begin{tabular}{|c|c|c|c|c|c|c|c|c|c|c|}
\hline & & Treatmes & & & & & & & & \\
\hline & Irrigatic & n schedule & S (IW/CPE) & Baby Corn & Crude pro- & Phosphorus & Potassium & Reducing & Ascorbic & Crude fiber \\
\hline & $\begin{array}{c}10-25 \\
\text { DAS }\end{array}$ & $\begin{array}{c}26-40 \\
\text { DAS }\end{array}$ & 41 DAS-Harvest & Heiu (t/ind) & $\operatorname{ten}(\%)$ & (\%) & (\%) & (mg/100g) & (mg/100g) & \\
\hline $\mathrm{I}_{1}$ & $: 1.0$ & 1.0 & 1.0 & 6.60 & 18.90 & 0.44 & 2.82 & 134.92 & 70.50 & 5.42 \\
\hline $\mathrm{I}_{2}$ & $: 0.6$ & 0.6 & 0.6 & 3.82 & 12.65 & 0.28 & 1.89 & 250.17 & 106.00 & 4.65 \\
\hline $\mathrm{I}_{3}$ & $: 0.6$ & 1.0 & 1.0 & 6.04 & 18.30 & 0.40 & 2.64 & 144.65 & 74.07 & 5.35 \\
\hline $\mathrm{I}_{4}$ & $: 1.0$ & 0.6 & 1.0 & 5.74 & 17.47 & 0.39 & 2.51 & 156.65 & 79.45 & 5.18 \\
\hline $\mathrm{I}_{5}$ & $: 1.0$ & 1.0 & 0.6 & 5.26 & 16.25 & 0.40 & 2.48 & 191.42 & 89.80 & 4.93 \\
\hline $\mathrm{I}_{6}$ & $: 0.6$ & 0.6 & 1.0 & 4.86 & 15.42 & 0.32 & 2.14 & 195.70 & 90.05 & 5.06 \\
\hline $\mathrm{I}_{7}$ & $: 1.0$ & 0.6 & 0.6 & 4.31 & 14.17 & 0.33 & 2.15 & 219.65 & 98.00 & 4.81 \\
\hline & & S.Em \pm & & 0.17 & 0.56 & 0.02 & 0.07 & 14.63 & 5.17 & 0.12 \\
\hline & & C.D. $(p=0$ & 05) & 0.49 & 1.59 & 0.05 & 0.19 & 41.46 & 14.65 & 0.34 \\
\hline
\end{tabular}

Table 4. Sensory parameters of baby corn as influenced by irrigation schedules (pooled data of 2002 and 2003).

\begin{tabular}{|c|c|c|c|c|c|c|c|c|}
\hline \multicolumn{4}{|c|}{ Treatment } & \multicolumn{5}{|c|}{ Sensory parameters } \\
\hline & \multicolumn{3}{|c|}{ Irrigation schedules (IW/CPE) } & \multirow[b]{2}{*}{ Appearance } & \multirow[b]{2}{*}{ Colour } & \multirow[b]{2}{*}{ Texture } & \multirow[b]{2}{*}{ Taste } & \multirow[b]{2}{*}{ Juiciness } \\
\hline & 10 - 25 DAS & 26 - 40 DAS & 41 DAS-Harvest & & & & & \\
\hline $\mathrm{I}_{1}$ & $: 1.0$ & 1.0 & 1.0 & 4.10 & 4.00 & 4.05 & 3.55 & 3.60 \\
\hline $\mathrm{I}_{2}$ & $: 0.6$ & 0.6 & 0.6 & 3.45 & 3.25 & 3.80 & 4.60 & 4.05 \\
\hline $\mathrm{I}_{3}$ & $: 0.6$ & 1.0 & 1.0 & 3.90 & 3.85 & 4.00 & 3.75 & 3.65 \\
\hline $\mathrm{I}_{4}$ & $: 1.0$ & 0.6 & 1.0 & 3.90 & 3.65 & 3.95 & 3.90 & 3.70 \\
\hline $\mathrm{I}_{5}$ & $: 1.0$ & 1.0 & 0.6 & 3.75 & 3.50 & 3.90 & 4.10 & 3.75 \\
\hline $\mathrm{I}_{6}$ & $: 0.6$ & 0.6 & 1.0 & 3.70 & 3.50 & 3.90 & 4.20 & 3.80 \\
\hline \multirow[t]{7}{*}{$\mathrm{I}_{7}$} & $: 1.0$ & 0.6 & 0.6 & 3.65 & 3.40 & 3.80 & 4.30 & 3.95 \\
\hline & & & $\overline{\text { Scale }}$ & Grade & & & & \\
\hline & & & 5 & $\overline{\text { Excellent }}$ & & & & \\
\hline & & & 4 & Very good & & & & \\
\hline & & & 3 & Good & & & & \\
\hline & & & 2 & Fair & & & & \\
\hline & & & 1 & Poor & & & & \\
\hline
\end{tabular}

the consumer acceptability of fresh baby corn, irrigation schedules differed with respect to sensory qualities like appearance, colour, taste and juiciness. With respect to raw baby corn, frequent irrigations at IW/CPE ratio of 1.0 throughout recorded higher values over rest of the treatments in respect of appearance, colour and texture of baby corn (Table 4). However, taste and juiciness of baby corn was very good under delayed irrigations at 0.6 IW/CPE ratio as against regular irrigations due to accu- mulation of sugars under moisture stress. The taste of baby corn increases with moisture stress and increases in accumulation of carbohydrates and sugars rather than protein and fiber. Further, sugars and protein are negatively correlated.

\subsection{Water Requirement and Water Use Efficiency (WUE)}

The total crop water use ranged from 294.1 to 469.1 
Table 5. Water requirement and water use efficiency of baby corn as influenced by irrigation schedules (Pooled data of 2002 and 2003).

\begin{tabular}{|c|c|c|c|c|c|c|c|}
\hline \multicolumn{4}{|c|}{ Treatment } & \multirow{3}{*}{$\begin{array}{l}\text { Total Water Re- } \\
\text { quirement (mm) }\end{array}$} & \multirow{3}{*}{$\begin{array}{l}\text { \% Water } \\
\text { saving }\end{array}$} & \multirow{2}{*}{\multicolumn{2}{|c|}{ Water use efficiency (kg/ha-mm) }} \\
\hline \multicolumn{4}{|c|}{ Irrigation schedules (IW/CPE) } & & & & \\
\hline & 10-25 DAS & 26-40 DAS & $\begin{array}{c}41 \\
\text { DAS-Harvest }\end{array}$ & & & Baby corn & Green fodder \\
\hline $\mathrm{I}_{1}$ & $: 1.0$ & 1.0 & 1.0 & 469.1 & - & 14.18 & 93.44 \\
\hline $\mathrm{I}_{2}$ & $: 0.6$ & 0.6 & 0.6 & 294.1 & 37.16 & 13.1 & 82.2 \\
\hline $\mathrm{I}_{3}$ & $: 0.6$ & 1.0 & 1.0 & 419.1 & 10.76 & 14.8 & 93.42 \\
\hline $\mathrm{I}_{4}$ & $: 1.0$ & 0.6 & 1.0 & 419.1 & 10.76 & 14.87 & 86.43 \\
\hline $\mathrm{I}_{5}$ & $: 1.0$ & 1.0 & 0.6 & 369.1 & 21.56 & 14.33 & 92.45 \\
\hline $\mathrm{I}_{6}$ & $: 0.6$ & 0.6 & 1.0 & 369.1 & 21.56 & 13.36 & 81.96 \\
\hline $\mathrm{I}_{7}$ & $: 1.0$ & 0.6 & 0.6 & 319.1 & 32.33 & 13.87 & 86.78 \\
\hline \multicolumn{4}{|c|}{ S.Em \pm} & & & 0.35 & 3.22 \\
\hline \multicolumn{4}{|c|}{ C.D. $(p=0.05)$} & & & 0.99 & 9.12 \\
\hline
\end{tabular}

mm respectively under continuously delayed irrigation at $0.6 \mathrm{IW} / \mathrm{CPE}$ ratio and regular irrigation at IW/CPE ratio of 1.0. Delayed irrigation throughout at $0.6 \mathrm{IW} / \mathrm{CPE}$ ratio $\left(\mathrm{I}_{2}\right)$ and from 26 DAS to harvest recorded $37.16 \%$ and $32.33 \%$ water saving over regular irrigation at 1.0 IW/CPE ratio throughout the crop growth. Delaying the irrigation at 10 - 25 DAS can also save $10.76 \%$ of water under scarced supply without greater compromise in yield.

Irrigating at IW/CPE ratio of 0.6 either throughout the crop growth or up to 40 DAS resulted in significantly lower WUE of baby corn and green fodder (13.10, 13.36 and 82.2, $81.96 \mathrm{~kg} \cdot \mathrm{ha}-\mathrm{mm}^{-1}$, respectively) over other treatments. Lower WUE can be ascribed to drastic reduction in the yield of baby corn and green fodder due to severe moisture stress caused during the grand growth period $\left(\mathrm{I}_{6}\right)$ and throughout the crop growth $\left(\mathrm{I}_{2}\right)$, despite lower water use (Table 5). Scheduling of irrigation at IW/CPE ratio of 0.6 either at early $\left(\mathrm{I}_{3}\right)$ or at mid $\left(\mathrm{I}_{4}\right)$ or at late stage $\left(I_{5}\right)$ or regular irrigations throughout at $1.0 \mathrm{IW} /$ CPE ratio caused significantly higher WUE over rest of the treatments but all these were on par with each other. This was due to the fact that there was no much reduction in yield under these stressed treatments with fairly lower water use. Despite the higher water use, WUE was also higher under 1.0 IW/CPE ratio throughout the crop growth $\left(\mathrm{I}_{1}\right)$ due to proportionate increase in the yield of baby corn and green fodder against water use. Sundarsingh [7] recorded higher water use and WUE at IW/CPE ratio of 1.0 over 0.5 and 0.75 ratios. However, Mahdi et al. [12] opined higher WUE at $1.0 \mathrm{E}_{0}$ over 0.6 and $0.8 \mathrm{E}_{0}$.

\section{CONCLUSIONS}

The results of the investigation have shown that scheduling irrigation for baby corn at $1.0 \mathrm{IW} / \mathrm{CPE}$ ratio throughout is desirable to obtain higher baby corn and green fodder yield under assured available irrigation water. However, under water scarce situation, delayed irrigation at $0.6 \mathrm{IW} / \mathrm{CPE}$ ratio could be given from 10 25 DAS with a marginal reduction in yield. Maintenance of higher plant water status helps to achieve higher baby corn and green fodder yield.

\section{REFERENCES}

[1] Prihar, S.S., Gagri, P.R. and Narang, R.S. (1974) Scheduling irrigation to wheat using pan evaporation. Indian Journal of Agricultural Sciences, 44, 567-571.

[2] Prihar, S.S., Khera, K.L., Sandhu, K.S. and Sandhu, B.S. (1976) Mulch, nitrogen and irrigation effects on growth, yield and nutrients uptake of forage corn. Agronomy Journal, 68, 937-941. doi:10.2134/agronj1976.00021962006800060023x

[3] Ranganna, S. (1986) Hand book of analysis and quality control for fruit and vegetable products. Tata McGrawHill Publishing, New Delhi, pp. 105-112.

[4] Nelson, N. (1944) A photometric adoption of the Somogyi method for the determination of glucose. The Journal of Biological Chemistry, 153, 375-380.

[5] Maynard, A.J. (1970) Methods in food analysis. Academic Press, New York, 176.

[6] Duncan, W.G. (1971) Leaf angle, leaf area and canopy photosynthesis. Crop Science, 11, 482-485. doi:10.2135/cropsci1971.0011183X001100040006x

[7] Sundarsingh, S.D. (2001) Effect of irrigation regimes and nitrogen levels on growth, yield and quality of baby corn. 
The Madras Agricultural Journal, 88, 367-370.

[8] Hussain, M.A., Ogunlela, V.B., Ramalan, A.A. and Falaki, A.M. (2001) Growth and development of maize (Zea mays L.) in response to different levels of nitrogen, phosphorus and irrigation. Crop Research, 22, 141-149.

[9] Kaliappa, R., Venkatachalam, S., Nachappan, K.M., Selvaraj, K.V. and Rajaram, S. (1974) Studies on water requirement of maize. The Madras Agricultural Journal, 61, 750-751.

[10] Singh, A.K., Singh, G.R. and Dixit, R.S. (1997) Influence of plant population and moisture regimes on nutrient up- take and quality of winter maize. Indian Journal of Agronomy, 42, 107-111.

[11] Bharathi, A., Vadivelu, K.K. and Umarani, R. (1997) Effect of irrigation management and nitrogen fertilization on shelf life of maize. The Madras Agricultural Journal, 84, 356-360.

[12] Mahdi, M., Al-Kaisi and Xinhua Yin (2003) Effect of nitrogen rate, irrigation rate and plant population on corn yield and water use efficiency. Agronomy Journal, 95, 1475-1482. doi:10.2134/agronj2003.1475 